\section{A Simple Technique For The Removal Of Plant Cell Protoplasm To Facilitate Scanning Electron Microscopy Of Fungal Haustoria And Plant Cell Wall Features}

B. A. Richardson* \& C. W. Mims, University of Georgia
"Beth @ dogwood.botany .uga.edu

Several years ago Honegger (1985) described a simple technique for removing plant cell protoplasm in order to reveal details of interfaces between plant cells and fungal structures. This technique involves the use of Ariel a commercially available washing powder (Proctor and Gamble) containing a Bacillus substilis derived protease. We since have used this technique with excellent results to examine not only the morphology of fungal haustoria inside leaf cells of various host plants but also features of the inner surface of the host cell wall with scanning electron microscopy (SEM). Here we describe the procedure we have used to prepare samples for study and provide examples of the types of images we have obtained from our samples.

In preparing samples it is important not to crush or distort plant cells. We have obtained best results by placing the leaf to be sampled on the surface of a plastic petri dish and then using a double edged razor to make slicing cuts of the leaf against the dish surface so as to yield long strips of smoothly cut tissue approximately $1 \mathrm{~mm}$ wide. These strips were placed in a $5 \%(w / v)$ aqueous solution of Ariel and incubated overnight (approximately 14 hours) at $30^{\circ} \mathrm{C}$. While shorter incubation times probably will work, we prefer the convenience of the overnight treatment. Following incubation, leaf strips were removed from the Ariel solution and washed for 30 minutes in multiple changes of distilled water. Samples then were fixed for 2 hours in $1 \%$ Osmium tetroxide at $4^{\circ} \mathrm{C}$. After fixation, samples were washed in multiple changes of distilled water for a total of 30 minutes, dehydrated in a graded series of ethanol to $100 \%$ ethanol and critical point dried. Leaf slices were mounted upright (cut surfaces up and down) on specimen stubs using a combination of carbon adhesive tabs and silver paste, sputter coated and examined with SEM.

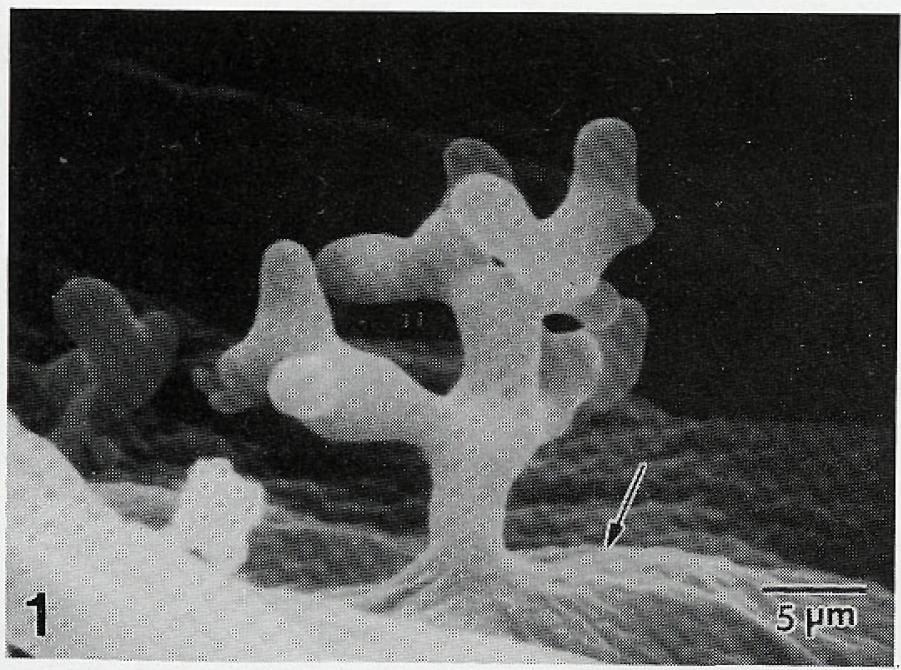

Figure 1. Branched haustorium of Cercosporidiurn personatum in a peanut leaf cell whose contents had been removed with Ariel. The inner surface of the host cell wall is visible at the arrow.
Haustoria, the fungal structures we routinely study, are specialized hyphal branches produced by a variety of plant pathogenic fungi. These structures appear to be involved in absorbing nutrients from living plant cells. They penetrate the host cell wall and invaginate the host plasma membrane so as to establish intimate contact with the protoplast of the host cell. Because the overall morphology of a haustorium can be difficult to deduce from the examination of the thin sections of samples required for transmission electron microscopy, we explored the use of Honegger's (1985) technique to expose haustoria for examination with SEM. Our initial efforts focused upon the highly branched haustoria of the peanut late leaf spot pathogen Cercosporidium personatum (Mims et al., 1989). As evident in Figure 1, we were able to obtain spectacular views of these haustoria within peanut leaf cells. Removal of the host cell protoplasm was so complete that the inner surfaces of host cell walls also were clearly visible. Since this initial work, we have used the Ariel treatment to examine haustoria of a variety of different types of fungi including those of Puccinia ara-

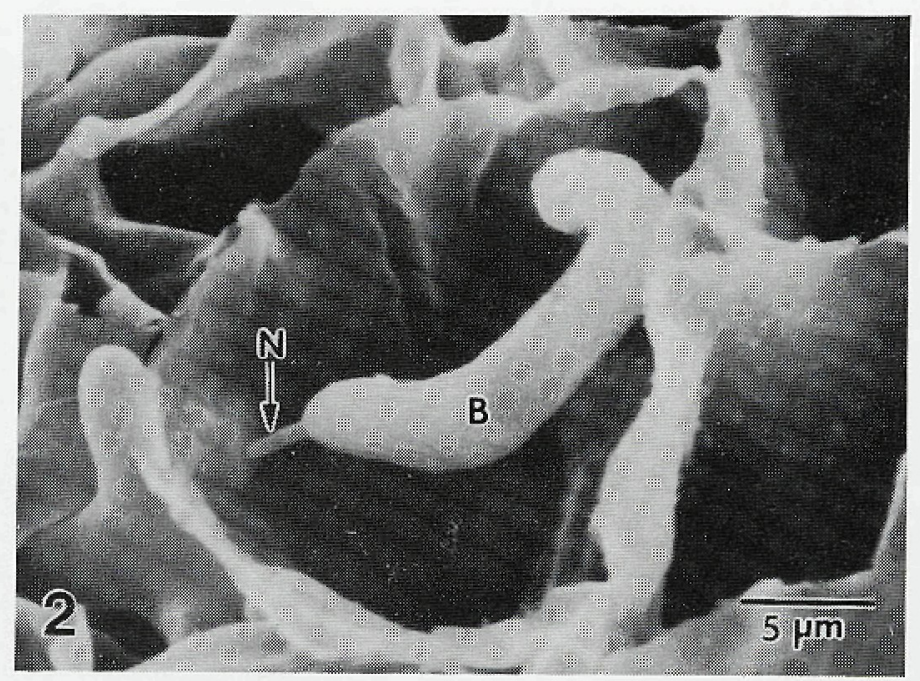

Figure 2. Distinctive haustorium of the rust fungus Puccinia arachis in a peanut leaf cell. Note the slender neck $(\mathrm{N})$ of the haustorium and its expanded body (B).

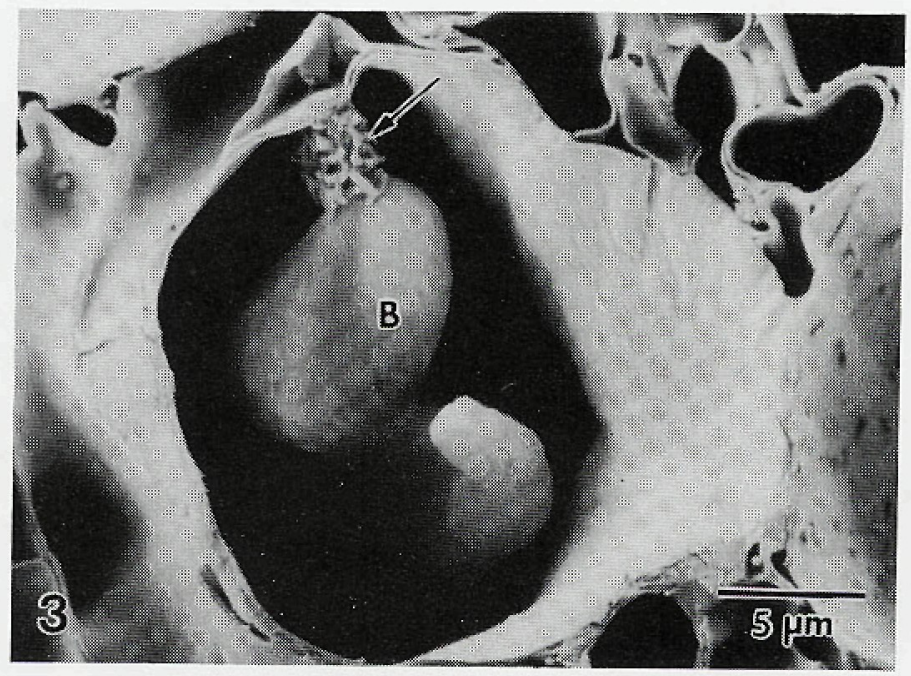

Figure 3. Haustorial body (B) of Fromme la mexicana var. indicae inside a leaf cell of Duchesnea indica. The slender neck of the haustorium is obscured by an elaboration of host cell wall material (arrow). 
chis (Figure 2), the cause of peanut rust disease, and those of Fromme la mexicana var. indicae, (Figure 3) the cause of rust disease of Duchesnea indica, a common weed known as Indian strawberry. As evident in Figure 2, the haustorium of $P$. arachis possesses a very slender basal neck region and an expanded haustorial body. The haustorium of $F$. mexicana var. indicae is similar in structure but its slender neck region eventually becomes obscured by an elaboration of host wall material (Figure 3). We (Mims et al., 2001) believe that this elaboration corresponds to wall elaborations present in transfer cells of various plants. Such cells are thought to be involved in intensive solute transfer over short distances. Figure 4 shows an example of such a wall elaboration surrounding the site at which a haustorium penetrated a host cell of $D$. indica. In this case, the haustorium became detached during sample preparation.

We believe the technique described here has multiple applications for the study of plant host cell structure and various hostpathogen interactions. The reliability and simplicity of the technique should make it attractive to a variety of researchers.

Mims, C. W., E. S. Luttrell and S. C. Alderman 1989. Ultrastructure of the haustorium of the peanut late leaf spot fungus Cercosporidium personatum. Can. J. Bot. 67: 1198-1202.

Mims, C. W., C. Rodriguez-Lother and E. A. Richardson. 2001. Ultrastructure of the host-pathogen interaction in leaves of Duchesnea indica infected by the rust fungus, Fromme la mexicana var. indicae as revealed by high pressure freezing. Can. J. Bot. (In Press).

Honegger, R. 1985. Scanning electron microscopy of the fungusplant interface: a simple preparative technique. Trans. Br. Mycol. Soc. 84: 530-533.

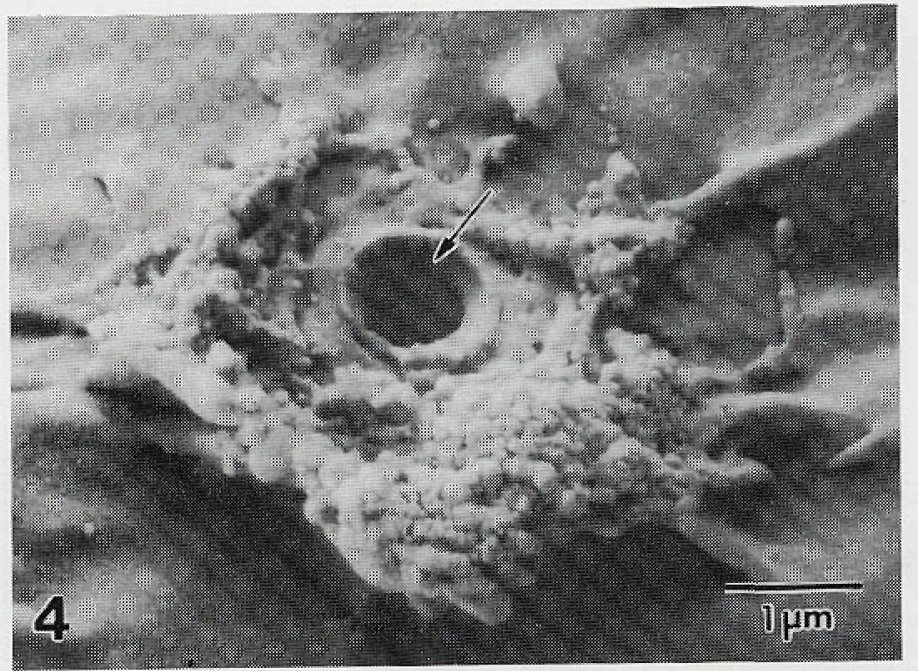

Figure 4. Elaboration of host cell wall material surrounding the penetration site (arrow) of a haustorium of Frornrne la mexicana var. indicae. The haustorium was lost during sample preparation.

\section{ADDENDUM}

Ariel may not be available in the United States, except possibly in California and Texas. There should be other detergents that use this protease and should readers know of any that are acceptable, they are invited to let Microscopy Today know and we will run a short article listing the acceptable substitutions.

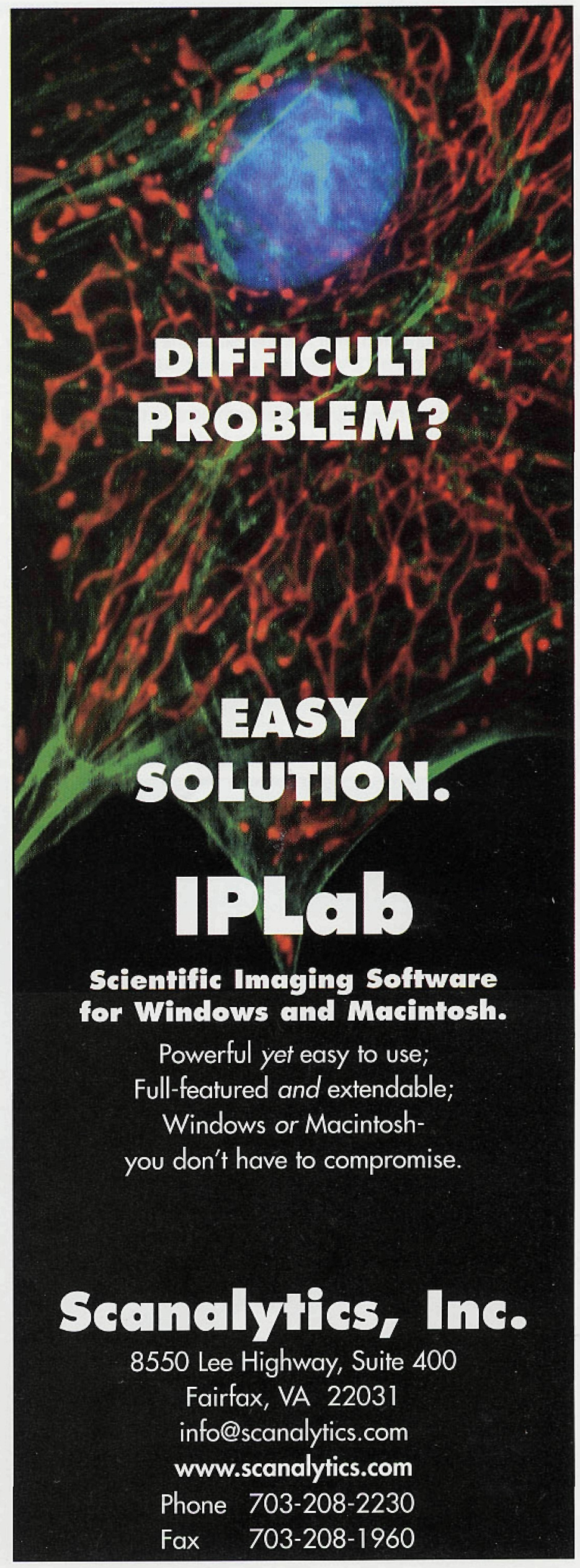

